\title{
Missed ascending colon cancer in an older patient with extensive ulcerative colitis
}

\author{
Kenji Tominaga, ${ }^{1}$ Yoshihisa Saida, ${ }^{2}$ Kei Takahashi, ${ }^{3}$ Iruru Maetani ${ }^{1}$
}

${ }^{1}$ Division of Gastroenterology and Hepatology, Department of Internal Medicine, Toho University Ohashi Medical Center, Tokyo, Japan ${ }^{2}$ Department of Surgery, Toho University Ohashi Medical Center, Tokyo, Japan ${ }^{3}$ Department of Surgical Pathology, Toho University Ohashi Medical Center, Tokyo, Japan

Correspondence to Dr Kenji Tominaga, kenjitominaga@hotmail.com

Accepted 9 February 2014

\section{CrossMark}

To cite: Tominaga $\mathrm{K}$, Saida Y, Takahashi K, et al. BMJ Case Rep Published online: [please include Day Month Year] doi:10.1136/ bcr-2014-203783

\section{DESCRIPTION}

A man in his early 70 s with a 15 -year history of extensive ulcerative colitis (UC) was referred for surveillance ileocolonoscopy (SI). He had no highrisk factors for UC-associated colorectal cancer $(\mathrm{CRC})^{1}$ except for the extent of active mucosal inflammation. Two years ago, he had undergone an SI with surveillance biopsy of the entire colorectum with no dysplasia or CRC detected. He had no surveillance the previous year despite a recommendation for annual SI. An ascending colon cancer was detected in the subsequent ileocolonoscopy (figure 1). There was no colorectal dysplasia, but biopsy revealed active mucosal inflammation throughout the colorectum including the peritumoural area. Proctocolectomy was performed and resected specimens revealed a moderately differentiated adenocarcinoma with subserosal invasion (figure 2). No histopathological characteristics of UC-associated $\mathrm{CRC}^{2}$ were detected. There was no synchronous dysplasia or CRC, and no metastasis. The patient remains alive without recurrence or metastasis 7 years after the proctocolectomy.

In contrast to sporadic microsatellite-stable CRC, UC-associated CRC is characterised by a relatively young age of onset, synchronous CRC and less frequent occurrence of right-sided tumours. ${ }^{2}$ In this case, although the cancer existed within an area of active mucosal inflammation, it was indistinguishable from a sporadic cancer due to the absence of the characteristic features of UC-associated CRC. Compared with older patients with non-inflammatory bowel disease, it has been reported that missed colorectal cancers among older patients with UC are less likely to occur in the right-sided colon. ${ }^{3}$

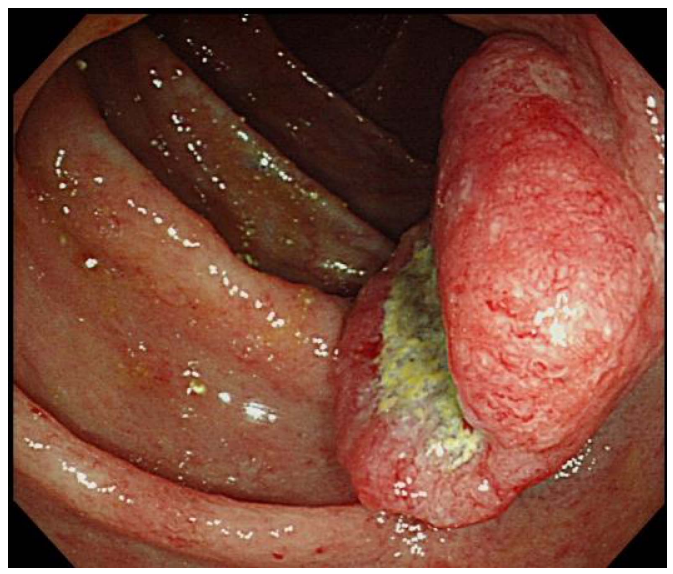

Figure 1 Colonoscopic view of the ascending colon cancer. An exophytic tumour (30 mm in diameter) with intraluminal growth was detected. There was active mucosal inflammation around the cancer.

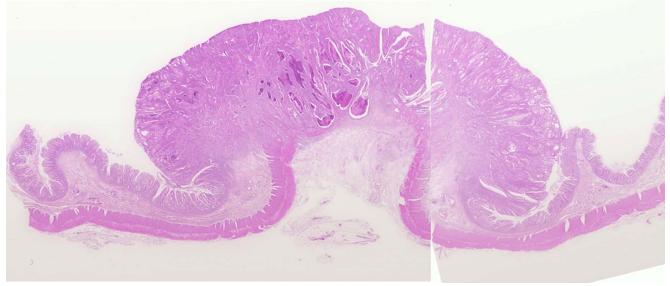

Figure 2 A histological specimen revealed a moderately differentiated adenocarcinoma with subserosal invasion $(\mathrm{H} \& \mathrm{E}$, original magnification, $\times 1)$. There was active mucosal inflammation, but no dysplasia around the cancer.

This case supports the use of meticulous SI, including for cancers in the right-sided colon, in older patients.

\section{Learning points}

- The European Crohn's and Colitis Organisation recommends that patients with high-risk features (stricture or dysplasia detected within the past 5 years, primary sclerosing cholangitis, extensive colitis with severe active inflammation or a family history of colorectal cancer in a first-degree relative under 50 years) should have annual surveillance colonoscopy.

- Compared with older patients with non-inflammatory bowel disease, it has been reported that early/missed colorectal cancers among older patients with ulcerative colitis are less likely to occur in the right-sided colon.

- For older patients with ulcerative colitis, it is important to consider right-sided tumours including sporadic cancers as well as ulcerative colitis-associated tumours.

Contributors TK performed the data collection, analysed the data and wrote the manuscript; SY and TK performed the data collection and analysed the data; MI performed the data collection, supervised the study and was involved in editing the manuscript. All authors approved the final version of the manuscript.

Competing interests None.

Patient consent Obtained.

Provenance and peer review Not commissioned; externally peer reviewed.

\section{REFERENCES}

1 Annese V, Daperno M, Rutter MD, et al. European evidence based consensus for endoscopy in inflammatory bowel disease. J Crohn's Colitis 2013;7:982-1018. 
2 Liu X, Goldblum JR, Zhao Z, et al. Distinct clinicohistologic features of inflammatory bowel disease-associated colorectal adenocarcinoma: in comparison with sporadic microsatellite-stable and Lynch syndrome-related colorectal adenocarcinoma. Am J Surg Pathol 2012;36:1228-33.
3 Wang YR, Cangemi JR, Loftus EV Jr., et al. Rate of early/missed colorectal cancers after colonoscopy in older patients with or without inflammatory bowel disease in the United States. Am J Gastroenterol 2013;108:444-9.

Copyright 2014 BMJ Publishing Group. All rights reserved. For permission to reuse any of this content visit http://group.bmj.com/group/rights-licensing/permissions.

BMJ Case Report Fellows may re-use this article for personal use and teaching without any further permission.

Become a Fellow of BMJ Case Reports today and you can:

- Submit as many cases as you like

- Enjoy fast sympathetic peer review and rapid publication of accepted articles

- Access all the published articles

- Re-use any of the published material for personal use and teaching without further permission

For information on Institutional Fellowships contact consortiasales@bmjgroup.com

Visit casereports.bmj.com for more articles like this and to become a Fellow 